\title{
Synthesis of high surface area zinc oxide supported copper catalysts and its catalytic activity studies on dehydrogenation of cyclohexanol
}

\section{Kumara Swamy Koppadi}

CSIR-Indian Institute of Chemical Technology (IICT)

\section{Nagaraju Nekkala}

CSIR-Indian Institute of Chemical Technology (IICT)

Bhanuchander Ponnala

CSIR-Indian Institute of Chemical Technology (IICT)

Hussain SK

CSIR-Indian Institute of Chemical Technology (IICT)

\section{Prem Kumar Seelam}

University of Oulu

\section{Vijayanand Perupogu}

CSIR-Indian Institute of Chemical Technology (IICT)

\section{Putrakumar Balla ( $\nabla$ bputrakumar@yahoo.com )}

Jiangxi University of Science and Technology

\section{Research Article}

Keywords: Rice grain, ZnO, Cu, Dehydrogenation, cyclohexanol, cyclohexanone

Posted Date: March 7th, 2022

DOl: https://doi.org/10.21203/rs.3.rs-1384871/v1

License: (c) (1) This work is licensed under a Creative Commons Attribution 4.0 International License. Read Full License 


\section{Abstract}

Rice-derived high surface area $\mathrm{ZnO}$ support (HSA-ZnO) is prepared by a novel thermal decomposition technique using rice grains as a sacrificial exo-template and zinc acetate trihydrate as an $\mathrm{ZnO}$ precursor. Further, copper supported HSA-ZnO catalysts with different copper loadings (4, 8, 12 and 16 wt.\%) were prepared by using wet impregnation method and characterized by various physicochemical techniques such as X-ray diffraction (XRD), thermo gravimetric analysis (TGA), BET surface area, temperature programmed techniques for $\mathrm{CO}_{2}$ desorption $\left(\mathrm{CO}_{2}\right.$-TPD) and reduction $\left(\mathrm{H}_{2}\right.$-TPR) and $\mathrm{N}_{2} \mathrm{O}$ pulse chemisorption measurements. The as-prepared $\mathrm{ZnO}$ support material exhibited moderately high surface area of $145 \mathrm{~m}^{2} / \mathrm{g}$, which is six times higher than commercial ZnO. The screening of Cu-modified HSA-ZnO catalysts were evaluated in the dehydrogenation of cyclohexanol to cyclohexanone reaction in a continuous flow reactor. In this work, the effect of temperature, the influence of copper loadings and the catalyst stability were thoroughly investigated. The catalyst exhibited varied properties with $\mathrm{Cu}$ loading and among the studied catalysts, $12 \mathrm{wt} . \% \mathrm{Cu} / \mathrm{HSA}-\mathrm{ZnO}$ catalyst exhibited highest cyclohexanol conversion of $75 \%$ and $89 \%$ cyclohexanone selectivity was achieved. The results were substantiated and confirmed by $\mathrm{N}_{2} \mathrm{O}$ pulse chemisorption and temperature programmed studies.

\subsection{Introduction}

Currently, the development of nanotechnology stimulates researchers to explore the salient features of new advanced materials at the nanostructure level[1]. In metal oxide nanostructures, the most relevant catalytic property is their large specific surface area, which is an important criterion and plays a vital role in numerous applications. Nevertheless, developing a new technique for the fabrication of metal oxides in nanoscale with a high specific surface area is an essential area of research.

The templating methods are standard technique and found to be effective and common in synthesizing metal oxides in micro and nanoscales[2][3]. Templating method had been used for many years in enhancing the physico-chemical properties of the materials. However, removing the template by either thermal or chemical treatment is highly complex and energy intensive. Nano casting is one method commonly used in successive templating and finally in template removal. The nano casting process is not easily scalable and has several synthesis steps required for preparing the template during impregnation. Recently, several authors presented a novel method in efficient implementation of templating and restructuring the metal oxides. For example, sacrificial template method is used to fabricate the metal oxide nanostructures based on rice grains (as a sacrificial template). Among several metal oxides, zinc oxide is one of the most versatile materials due to its vast area of applications and unique properties, for example, in catalysis, gas sensor, biosensor, cosmetics, storage, optical devices, window materials for displays, solar cells, and drug-delivery[4][5][6].

White Rice grains generally have $68 \%$ water, $28 \%$ carbohydrates, and $3 \%$ proteins. Rice can be cooked in boiling water, and a great amount of water was absorbed during the cooking process and providing a route to dispersing the precursors into the rice grains. During calcination under air, the organic moieties 
(carbohydrates and protein linkages) of white rice grains decomposed into different gaseous molecules such as carbon dioxide, carbon monoxide and water vapor. Moreover, white rice grains act as key sacrificial materials in synthesizing high surface area $\mathrm{ZnO}$ via decomposition of rice grains into gaseous molecules and thus, creates new pores over the surface of $\mathrm{ZnO}$ via re-structing and condensation. Thus, rice grains are utilized as a sacrificial exo-template in enhancing the surface area of the $\mathrm{ZnO}$.

The cyclohexanol (Cyhol) dehydrogenation reaction to cyclohexanone (Cyhon) is of great importance in the caprolactam manufacturing process and it is used as an intermediate in pharmaceutical drugs (such as in the production of pentylenetetrazol, laurocapram and meptazinol). It is a common intermediate in the synthesis of adipic acid and studying this dehydrogenation is a good model reaction in correlating structure-activity relationships. Cyhol dehydrogenation is a important reaction process in an industrial point of view in the production of cyclohexanone (Cyhon). Moreover, Cyhon is used as an industrial solvent for dyes, paints and pesticide and this reaction is thermodynamically reversible and highly endothermic in nature [7][8][9][10][11][12]. During the vapor phase dehydrogenation of Cyhol, other side reactions such as dehydration of Cyhol followed by dehydrogenation and aromatization of Cyhol are possible. Cyhon is formed as the desired product during the dehydrogenation Cyhol, and also other common byproduct formation might take place such as cyclohexene (Cyhene), Benzene (Bn), Cyclohexenone (Cyhenon) and Phenol (Phol) formation. Thus, byproduct formation is solely depends on the reaction conditions and catalyst type[13]. Typically, two different types of catalysts are employed in dehydrogenation of Cyhol to Cyhon at two different reaction temperatures. The copper based catalysts are commonly used in vapor phase dehydrogenation of Cyhol at low temperature range i.e., 473-573 K and zinc-calcium based catalysts are employed at high temperature range i.e., 623-723 K [14].

The vapor phase catalytic dehydrogenation of Cyhol to Cyhon have been studied over mono, bi-, and trimetallic catalytic systems such as $\mathrm{Cu}-\mathrm{ZnO}-\mathrm{SiO}_{2}$ [13], Cu-MgO[9], Cu-SBA-15[15][16], Cu-Al ${ }_{2} \mathrm{O}_{3}$ [17][11], $\mathrm{CuCr}_{2} \mathrm{O}_{4}, \mathrm{Cu}-\mathrm{ZnO}$-Graphite[10], CuCo-SiO ${ }_{2}[18]$, gamma-Al $\mathrm{O}_{3} / \mathrm{a}-\mathrm{Al}_{2} \mathrm{O}_{3}[19], \mathrm{FeTi} / \mathrm{MCM}-41$ [20], AlPO ${ }_{4}[21]$, $\mathrm{CuNi}-\mathrm{CeO}_{2}$ [22], $\mathrm{AuMgCuCr} \mathrm{O}_{4}$ [23]. In one study, over $\mathrm{Cu} / \mathrm{ZrO}_{2}$ catalysts, presented a high yield of Cyhon $57 \%$ and benzene $79 \%$. The products formation and distribution depends on the $\mathrm{ZrO}_{2}$ phase in $\mathrm{Cu} / \mathrm{ZrO}_{2}$ catalysts, which are synthesized by impregnation and co-precipitation methods[24]. Recently reported a $\mathrm{AuMgCu} / \mathrm{Cr}_{2} \mathrm{O}_{4}$ catalyst shown a high yield of Cyhon $69.5 \%$ and $86.4 \%$ at 533 and $573 \mathrm{~K}$, respectively[25]. It is evident that, reaction temperature, catalyst preparation method, and support structure can influence the reaction performance. For example, mono- and bi- promoters based catalysts such as $\mathrm{Cu} / \mathrm{ZnO}-\mathrm{Cr}_{2} \mathrm{O}_{3}$ and $\mathrm{Cu} / \mathrm{ZnO}-\mathrm{Cr}_{2} \mathrm{O}_{3}-\mathrm{La}_{2} \mathrm{O}_{3}$ exhibited different yield values i.e., $51 \%$ and $61.5 \%$ of Cyhon at $523 \mathrm{~K}$ in the presence of $\mathrm{CO} / \mathrm{CO}_{2}[26]$. Some of the reported copper-based catalysts are employed in the vapor phase dehydrogenation of Cyhol at high temperatures. The sintering of metallic copper particles occurs at higher temperatures; thus, it is appropriate to use at lower temperatures. In this work, we synthesized a high surface area $\mathrm{ZnO}$-supported copper catalysts (Cu/HAS-ZnO) and its performance in dehydrogenation Cyhol to Cyhon at lower temperatures were evaluated. In this work as-prepared and modified nano-scaled support structure is used in Cyhol dehydrogenation reaction. Wherein presented a superior catalytic performance and stability as compared to commercial catalyst. We report a high 
surface area $\mathrm{ZnO}$ prepared by using a sacrificial template method in which rice grains as templating agent. A series of $\mathrm{Cu} / \mathrm{HSA}-\mathrm{ZnO}$ catalysts with various copper loadings were synthesized and tested in dehydrogenation of Cyhol reaction. The catalysts were characterized using different physicochemical techniques.

\subsection{Experimental}

\subsection{Materials and methods}

A facile in-situ thermal decomposition method is used in preparing a high surface area (HAS) zinc oxide (ZnO). A $10 \mathrm{~g}$ of zinc acetate (SD fine chemicals Ltd.) was dissolved in $250 \mathrm{~mL}$ distilled water. In next step, a $20 \mathrm{~g}$ of washed and dried rice grains was added into the resultant zinc acetate solution. The mixture (Zn precursor + rice grains) was cooked for $24 \mathrm{~h}$ at $353 \mathrm{~K}$ and the resultant white color dried solid was dried in oven at $373 \mathrm{~K}$ for $12 \mathrm{~h}$. The obtained white color solid mass was calcined at $773 \mathrm{~K}$ for $4 \mathrm{~h}$ in the presence of airflow. The resultant white colored solid is the rice derived high surface area $\mathrm{ZnO}$; it is denoted as HSA-ZnO. Using $\mathrm{Cu}\left(\mathrm{NO}_{3}\right)_{2} \cdot 3 \mathrm{H}_{2} \mathrm{O}$ (Sigma-Aldrich, USA, 99.9\%) as a copper precursor calculated with nominal loadings $(5,10,15$ and 20 wt.\% of copper) were prepared by impregnation method. The required amount of copper nitrate was dissolved in water and then HSA-ZnO support was added slowly, which was dried at $343 \mathrm{~K}$ until complete moisture removal and then further dried for $12 \mathrm{~h}$ in oven at 373 $\mathrm{K}$. In next step, the dried samples were calcined at $623 \mathrm{~K}$ under air flow for $8 \mathrm{~h}$ [27][28][29][30]. A comparison study was made between a commercial low surface area $\mathrm{ZnO}$ based $\mathrm{Cu}$ catalyst ad the lab made HAS ZnO catalyst in optimized reaction conditions.

\subsection{Characterization}

Series of physisorption experiments were carried out to evaluate the textural properties. The BET surface area was calculated using Quadrasorb-SI V 5.06, adsorption unit (M/s. Quanta chrome Instruments Corporation, USA) under $\mathrm{N}_{2}$ adsorption at $77 \mathrm{~K}$. The samples were degassed at $573 \mathrm{~K}$ for $4 \mathrm{~h}$ before the measurement. Thermal gravimetric analysis (TGA) of dried HSA-ZnO and 10Cu/HSA-ZnO was carried out using TGA/SDTA 851e thermal system (Mettler Toledo, Switzerland). During the analysis, the sample was heated under air from $300 \mathrm{~K}$ to $1050 \mathrm{~K}$ at a heating rate of $10 \mathrm{~K} \cdot \mathrm{min}^{-1}$. The X-ray diffraction (XRD) patterns were recorded at room temperature using a Rigaku Ultima-IV diffract meter with nickel filtered Cu- $\mathrm{K}_{\mathrm{a}}$ radiation of wavelength $1.5418 \AA$ at a power of $40 \mathrm{kV}$ and a current of $20 \mathrm{~mA}$ in the $2 \theta$ range of 10$80^{\circ}$ to confirm the crystalline phases of copper species presented in the reduced $\mathrm{Cu} / \mathrm{HSA}-\mathrm{ZnO}$ catalysts.

The temperature-programmed reduction of hydrogen $\left(\mathrm{H}_{2}\right.$-TPR) was conducted in TPR system. Typically, a $50 \mathrm{mg}$ of calcined CuO/HSA-ZnO sample was loaded in a quartz reactor and heated up to $473 \mathrm{~K}$ for $1 \mathrm{~h}$ under argon gas flow ( $\left.30 \mathrm{~mL} \cdot \mathrm{min}^{-1}\right)$. After being cool down to room temperature, the sample was heated to $973 \mathrm{~K}$ at a rate of $10 \mathrm{~K} \cdot \mathrm{min}^{-1}$ under $5 \mathrm{vol} \% \mathrm{H}_{2} / \mathrm{Ar}$ flow $\left(30 \mathrm{~mL} \cdot \mathrm{min}^{-1}\right)$. The hydrogen consumption was monitored using GC equipped with thermal conductivity (TCD) unit. The total basicity of the catalysts was measured by temperature-programmed desorption of $\mathrm{CO}_{2}$. In a typical experiment, $0.1 \mathrm{~g}$ of catalyst 
was loaded and pre-treated in a helium flow $\left(99.9 \%, 50 \mathrm{~mL} \cdot \mathrm{min}^{-1}\right)$ at $573 \mathrm{~K}$ for $1 \mathrm{~h}$. After pre-treatment, the sample was saturated with 10 vol. $\% \mathrm{CO}_{2}$ balanced with helium gas at $373 \mathrm{~K}$ for $1 \mathrm{~h}$ and subsequently flushed with helium gas for $1 \mathrm{~h}$ to remove the physisorbed $\mathrm{CO}_{2}$. The TPD of the catalysts was carried out from $373 \mathrm{~K}$ to $1000 \mathrm{~K}$ under helium flow $\left(99.9 \%, 30 \mathrm{~mL} \cdot \mathrm{min}^{-1}\right)$ with a temperature ramp of $10 \mathrm{~K} \cdot \mathrm{min}^{-1}$ and the desorbed $\mathrm{CO}_{2}$ was measured using GC equipped with TCD. The $\mathrm{N}_{2} \mathrm{O}$ pulse chemisorption was carried out at $303 \mathrm{~K}$ on a pulse reactor to measure and analyse the copper dispersion and particle size. Typically, about $100 \mathrm{mg}$ of catalyst was placed in a reactor of $8 \mathrm{~mm}$ i.d. and then the catalyst was reduced under a hydrogen flow at $523 \mathrm{~K}$ for $3 \mathrm{~h}$, and then pre-treated at $523 \mathrm{~K}$ for $1 \mathrm{~h}$ under helium flow and finally, cool down to $303 \mathrm{~K}$. The reactor outlet was connected to a micro-thermal conductivity detector (TCD) equipped GC-17A (M/s. Shimadzu Instruments, Japan) through an automatic six-port valve (M/s. Valco Instruments U.S.A). After cooling the reactor to the required temperature, the pulse of $10 \mathrm{vol} . \% \mathrm{~N}_{2} \mathrm{O}$ (balanced with $\mathrm{He}$ ) were injected into the catalyst bed at room temperature through a $1 \mathrm{~mL}$ loop connected to the six-port valve until no change in the intensity of the outlet $\mathrm{N}_{2} \mathrm{O}$ (from GC-software). In this chemisorption, assuming $\mathrm{N}_{2} \mathrm{O}: \mathrm{Cu}$ stoichiometry of $1: 2$ and Cu metal cross-sectional area of $6.8 \times 10^{-}$ ${ }^{20} \mathrm{~m}^{2} \mathrm{Cu}$ atom ${ }^{-1}$ was considered.

\subsection{Catalyst activity test}

The vapor phase dehydrogenation of Cyhol to Cyhon over Cu/HSA-ZnO catalysts was studied in a fixed bed down-flow glass reactor ( $14 \mathrm{~mm}$ id and $300 \mathrm{~mm}$ long) under atmospheric pressure with the temperature range of $453-533 \mathrm{~K}$. In this activity test, around $0.5 \mathrm{~g}$ of catalyst was mixed with the equal amount of quartz grains and the mixture was placed in between the two quartz wool plugs in a reactor. The catalyst and quartz beads are packed below the preheating zone for the reactants. Before the reaction, the catalyst was reduced at $523 \mathrm{~K}$ for $3 \mathrm{~h}$ with a $\mathrm{H}_{2}$ flow rate of $30 \mathrm{~mL}$. $\mathrm{min}^{-1}$. After reduction, the initial required reaction temperature was set, and Cyhol was fed with a flow rate of $1 \mathrm{~mL} \cdot \mathrm{h}^{-1}$ with carrier gas $\mathrm{N}_{2}$ flow $\left(25 \mathrm{~mL} \mathrm{~min}{ }^{-1}\right)$. The bottom of the reactor is attached to the ice-cold trap. The gaseous and vapor products were collected from ice trap at regular intervals and analyzed with EB- 5 capillary column (30 m length, $0.53 \mathrm{~mm}$ I.D and 5.0 $\mathrm{mm}$ film thickness) of gas chromatography, GC-17A (M/s. Shimadzu Instruments, Japan) equipped with flame ionization detector and all liquid products were analysed with EB- $5 \mathrm{MS}$ capillary column $(30 \mathrm{~m} \times 0.25 \mathrm{~mm} \times 0.25 \mu \mathrm{m})$ of GC-MS, QP-2010 (M/s. Shimadzu Instruments, Japan)

\subsection{Results And Discussion}

The thermal behavior of the prepared samples can be determined by using TGA technique. Thermo gravimetric analysis of the dried HSA-ZnO, zinc acetate, and rice grains were shown in Fig. 1. We found that the weight loss was found in all the samples at different stages at different temperatures. The significant weight loss was evident due to thermal treatment. Weight losses of the three samples are classified at three stages with three different thermograms. Initially, a $10.2 \mathrm{wt} . \%$ loss of the rice grain at temperature $532 \mathrm{~K}$ was found and can be attributed to the loss of physically adsorbed water molecules. 
The second and third stages of weight losses of the rice grains are corresponding to that of organic moieties (e.g., monosaccharide linkages) converted into carbon dioxide and water during the thermal decomposition under air. From Fig. 1 the rice grains undergone $100 \%$ weight loss after complete thermal treatment up to $1000 \mathrm{~K}$. Thus, it was clearly indicating that the rice grains can be used as a potential sacrificial exo-template in the synthesis of high surface area zinc oxide support due to its complete decomposition \& surface templating. A significant $14.3 \mathrm{wt}$ \% loss of zinc acetate sample at $393 \mathrm{~K}$ is due to the evaporation of adsorbed water molecules over the zinc acetate surface and also the coordinated hydrated molecules with zinc. The second and third stages of weight loss may be ascribed due to the step-wise pyrolysis of acetate skeleton. The total weight loss of the zinc acetate is around $\sim 85 \mathrm{wt} . \%$. The first stage weight loss of $5 \mathrm{wt} . \%$ of the dried HSA-ZnO attributed to the loss of physically adsorbed $\mathrm{H}_{2} \mathrm{O}$ molecules over the surface. The second and third stages of weight losses corresponds to the decomposition of the organic moieties of rice grains and acetate moiety of zinc acetate. The decomposition process of rice grains resulted into release of large number of gaseous products and vapors. Moreover, during the decomposition and evaporation, the development of new porosity and enhancement of $\mathrm{ZnO}$ surface area occur. The surface area of HSA-ZnO and $\mathrm{Cu} / \mathrm{HSA}-\mathrm{ZnO}$ catalysts were determined by the BET surface area method and the values are presented in Table 1. From Figure S2, depicted the nitrogen adsorption-desorption isotherms and the corresponding pore size distribution calculated by BJH method for 12 wt.\% Cu/HSA-ZnO catalyst. The BET specific surface area, total pore volume, and average pore diameter are also included in the Fig. S2. The 12Cu/HSA-ZnO exhibited hysteresis loop in the relative pressure of 0.3 to 0.93 , indicating the existence of mesoporous nature. The specific surface area of the resultant HSA-ZnO obtained by sacrificial templating method using rice grains is relatively high compared to commercial $\mathrm{ZnO}$. The increase in surface area during the volatilization process occur due to the loss of volatile organic compounds from the rice grain's hold space, which eventually increased the porosity of the materials. The pore size distribution curve shows that the 12Cu/HSA-ZnO exhibit a more abundant porous structure, and moreover, the pore size distribution is non-uniform with tiny pores centered between $0-25 \mathrm{~nm}$ in diameter. From Table.1, as predicted, the surface area for the copper supported catalysts decreased with copper loadings.

The XRD patterns of dried HSA-ZnO and calcined $\mathrm{Cu} / \mathrm{HSA}-\mathrm{ZnO}$ catalysts were shown in Fig. 2. The peaks at $2 \theta$ values $31.67^{\circ}, 34.31^{\circ}, 36.14^{\circ}, 47.40^{\circ}, 56.52^{\circ}, 62.73^{\circ}, 66.28^{\circ}, 67.91^{\circ}$, and $69.03^{\circ}$ are corresponds to (100), (002), (101), (102), (110), (103), (200), (112) and (201) planes of ZnO, which indicate that the samples were polycrystalline with wurtzite structure (Zincite, JCPDS 5-0064)[31]. The remaining wellresolved peaks were assigned to the $\mathrm{CuO}$ species. Some of the intensity peaks $\mathrm{ZnO}$ are merged with the $\mathrm{CuO}$ peaks. Further, the intensity of $\mathrm{CuO}$ peaks increased with copper loadings of the impregnated catalysts.

Table1. The BET surface area, $\mathrm{H}_{2}$ consumption and ICP-OES of $\mathrm{Cu} / \mathrm{HSA}-\mathrm{ZnO}$ catalysts. 


\begin{tabular}{|c|c|c|c|c|c|}
\hline Catalyst code & $\begin{array}{l}\begin{array}{l}\text { Surface } \\
\text { area }\end{array} \\
\left(\mathrm{m}^{2} / \mathrm{g}\right)^{\mathrm{a}}\end{array}$ & $\begin{array}{l}\text { Crystallite } \\
\mathrm{Cu}(111)^{\mathrm{b}}\end{array}$ & size of & $\begin{array}{l}\text { Hydrogen } \\
\text { consumption } \\
(\mu \mathrm{mol} / \mathrm{g})^{\mathrm{c}}\end{array}$ & $\begin{array}{l}\begin{array}{l}\text { Total } \\
\text { basicity }\end{array} \\
(\mu \mathrm{mol} / \mathrm{g})^{d}\end{array}$ \\
\hline HSA-ZnO & 145 & - & & - & 365 \\
\hline 4Cu/ HSA-ZnO & 132 & 10 & & 37.1 & 352 \\
\hline $8 \mathrm{Cu} / \mathrm{HSA}-\mathrm{ZnO}$ & 118 & 15 & & 85.5 & 338 \\
\hline $\begin{array}{l}12 \mathrm{Cu} / \mathrm{HSA}- \\
\mathrm{ZnO}\end{array}$ & 109 & 18 & & 163.2 & 321 \\
\hline $\begin{array}{l}16 \mathrm{Cu} / \mathrm{HSA}- \\
\mathrm{ZnO}\end{array}$ & 92 & 25 & & 281.4 & 297 \\
\hline
\end{tabular}

a Surface area calculated from $\mathrm{BET},{ }^{\mathrm{b}}$ Crystallite size of $\mathrm{Cu}(111)$ calculated from XRD, ${ }^{\mathrm{C}}$ Hydrogen consumption calculated from TPR, ${ }^{\mathrm{d}} \mathrm{CO}_{2}$-TPD.

The XRD pattern of reduced $\mathrm{Cu} / \mathrm{HSA}-\mathrm{ZnO}$ catalysts is shown in Fig. 3, herein, the well-resolved peaks of $2 \theta$ values at $43.2^{\circ}, 50.3^{\circ}$, and $74.16^{\circ}$ confirm the presence of metallic copper $(\mathrm{Cu}(0))$ according to JCPDS-04836. Moreover, the metallic copper peak intensity increased with the copper loadings. From XRD analysis, we can conclude that there are no other copper phases were detected. The crystallite size of $\mathrm{Cu}(111)$ is calculated from the Debye Scherer equation, and these values are depicted in Table 1.It is clearly presented that the size of copper crystallite increased with the copper loading.

The reduction behavior of calcined copper supported $\mathrm{ZnO}$ catalysts was examined by temperature programmed reduction technique using molecular hydrogen. The $\mathrm{H}_{2}$-TPR profiles of calcined catalysts are depicted in Fig. 4. Reducibility of the copper mainly depends on various parameters such as dispersion of copper, copper oxide-support interactions and size of the copper particle. The TPR profile of the $4 \mathrm{Cu} / \mathrm{HSA}-\mathrm{ZnO}$ and $8 \mathrm{Cu} / \mathrm{HSA}-\mathrm{ZnO}$ presented a broad peak at the low temperature region, indicating the presence of highly dispersed $\mathrm{Cu}$ species. Highly dispersed copper oxide species tend to reduce at very low temperatures compared to the bulk $\mathrm{CuO}$ species, which tends to reduce at high temperatures. The 12Cu/HSA-ZnO catalyst exhibits two reduction peaks in the TPR profiles, and these peaks are associated to the successive reduction of isolated $\mathrm{Cu}$ ions at low temperatures followed by the reduction of bulk $\mathrm{CuO}$ at higher temperatures. Typically, $\mathrm{Cu}$ oxide species tends to follow two-step reduction process: $\mathrm{Cu}(+2) \rightarrow \mathrm{Cu}(+1) \rightarrow \mathrm{Cu}(0)$. A similar two-step $\mathrm{Cu}(\mathrm{II})$ reduction process was also observed for the $\mathrm{CuO} / \mathrm{ZnO}$ catalysts [32].

Nevertheless, we found that the $16 \mathrm{wt} . \% \mathrm{Cu} / \mathrm{HSA}-\mathrm{ZnO}$ catalyst shown only a single reduction peak at high temperature region (at 548K). It may be due to the presence of large and bulk copper oxide particles compared to other $\mathrm{Cu} / \mathrm{HSA}-\mathrm{ZnO}$ catalysts. The intensity of the main reduction peak and the position of $\mathrm{T}_{\mathrm{Max}}$ of the catalysts shifted to high temperature region with $\mathrm{Cu}$ loadings i.e., from 4 to $16 \mathrm{wt}$ \%. This 
indicates that the, a highly dispersed $\mathrm{Cu}$ crystallites are more pronounced at lower $\mathrm{Cu}$ loadings. The support-surface metal interactions are relatively strong at lower reduction temperature and at lower $\mathrm{Cu}$ loadings than the bulk CuO. From the Table.1 as expected, that the $\mathrm{H}_{2}$ consumption increased with $\mathrm{Cu}$ loadings. According to TPR profiles, $\mathrm{T}_{\mathrm{Max}}$ trend of the catalysts as follows: 4Cu/HSA-ZnO-T $\mathrm{Max}_{\mathrm{M}-53}<$ 8Cu/HSA-ZnO-T Max-528 $<12 \mathrm{Cu} / \mathrm{HSA}-Z \mathrm{nO}-\mathrm{T}_{\text {Max-535 }}<8 \mathrm{Cu} / \mathrm{HSA}-\mathrm{ZnO}-\mathrm{T}_{\text {Max-548. }}$. For comparison, the TPR curve of 12Cu-LSA-ZnO is also reported, and also which was prepared from the decomposition of zinc acetate (Fig. S4). Only a single peak occurred at a high temperature region due to the existence of bulk CuO species. The $T_{\max }$ of the $12 \mathrm{Cu} / \mathrm{LSA}-\mathrm{ZnO}$ is higher than the $12 \mathrm{Cu}-\mathrm{HSA}-\mathrm{ZnO}$. According to previous studies, bulk $\mathrm{CuO}$ is reduced at higher temperatures [33].

Temperature programmed desorption of $\mathrm{CO}_{2}$ is a well-known technique to determine the total basicity of the catalysts. The TPD of $\mathrm{CO}_{2}$ profiles of HSA-ZnO and $\mathrm{Cu} / \mathrm{HSA}-\mathrm{ZnO}$ catalysts were depicted in Fig.5. and the total amount of $\mathrm{CO}_{2}$ desorbed is listed in Table 1.

According to literature, the basic sites are usually categorized into three types, weak (323-473k), medium (473-773k), and strong (773-923) basicity strength [34].The TPD profile of HSA-ZnO presents only one intense desorbed peak in the temperature range of 400 to $625 \mathrm{~K}$ suggests that the existence of medium basic sites. As we can see from the Table 1, HSA-ZnO catalyst shown high basicity compared to the $\mathrm{Cu}$ modified $\mathrm{HSA}-\mathrm{ZnO}$ catalysts and thus, it clearly indicates that the $\mathrm{Cu}$ incorporation lowers the support basicity due to the Cu coverage. The TPD spectrum of the 4Cu HSA-ZnO sample shows a composite signal with a maximum of $650 \mathrm{~K}$ and a long tail extending up to $1000 \mathrm{~K}$. This indicates the wide distribution of strong basicity strength, transition from weak to strong at low loadings. The tail peak of $\mathrm{CO}_{2}$ is related to the interaction with the strong basic sites, which are probably associated with $\mathrm{Cu}^{2+}$ cations. The total basicity decreased with the increase of copper loadings due to weak $\mathrm{CO}_{2}$ adsorption [35][36]. The difference in the volume of $\mathrm{CO}_{2}$ desorption for the $\mathrm{Cu}$ incorporated catalysts specifies the existence of $\mathrm{Cu}$ ions has a substantially impacted the basicity character of the $\mathrm{ZnO}$ support.

The $\mathrm{N}_{2} \mathrm{O}$ pulse decomposition method is a well known technique to determine the copper active surface area. $\mathrm{N}_{2} \mathrm{O}$ pulse decomposition and ICP results are summarized in Table 2. The copper loading measured from ICP analysis is almost near to calculated value. From Table 2, It was observed that the metal area of copper is increased up to $12 \mathrm{wt} \%$ of copper on HSA-ZnO due to the existence of a maximum number of dispersed $\mathrm{Cu}$ sites that are available on the surface. However, the metal area is found to decrease with copper loading above $12 \mathrm{wt} \%$. The XRD studies well support these results.

Table.2 ICP-OES and $\mathrm{N}_{2} \mathrm{O}$ decomposition values of $\mathrm{Cu} / \mathrm{HSA}-\mathrm{ZnO}$ catalysts. 


\begin{tabular}{|llll|}
\hline Catalyst & $\begin{array}{l}\text { ICP-OES } \\
\text { (Cu\%) }\end{array}$ & $\begin{array}{l}\mathrm{H}_{2} \\
\text { Uptake }(\mathrm{mmol})\end{array}$ & Cu surface area ${ }^{\mathrm{b}}\left(\mathrm{m}^{2} / \mathbf{g}_{\text {Catalyst }}\right)$ \\
\hline 4Cu/ HSA-ZnO & 3.5 & 1.073 & 3.92 \\
\hline 8Cu/ HSA-ZnO & 7.2 & 1.246 & 4.55 \\
\hline 12Cu/ HSA-ZnO & 11.4 & 1.440 & 5.26 \\
\hline 16Cu/ HSA-ZnO & 14.9 & 1.283 & 4.69 \\
\hline
\end{tabular}

${ }^{a}$ metal wt.\% calculated from ICP-OES ${ }^{b}$ Results from $\mathrm{N}_{2} \mathrm{O}$ pulse Decomposition technique

\subsection{Catalyst activity results}

Gas phase dehydrogenation of Cyhol to Cyhon was studied over Cu modified HSA-ZnO catalysts in the temperature range of $453-533 \mathrm{~K}$ under ambient pressure. The reaction pathways and products distribution of Cyhol dehydrogenation reaction is represented in the Scheme. 1. The Cyhon is the major product, and Cyhene, Cyhenon, Phol, and Bn are the minor products in the dehydrogenation of Cyhol.

\section{Effect of copper loadings}

The vapor phase dehydrogenation of Cyhol to Cyhon was performed over reduced 4Cu/HSA-ZnO, $8 \mathrm{Cu} / \mathrm{HSA}-\mathrm{ZnO}, 12 \mathrm{Cu} / \mathrm{HSA}-\mathrm{ZnO} 16 \mathrm{Cu} / \mathrm{HSA}-\mathrm{ZnO}$ catalysts at the temperature of $453 \mathrm{~K}$ under atmospheric pressure and to investigate the effect of $\mathrm{Cu}$ loading (Fig. 6). The catalysts were reduced at $573 \mathrm{~K}$ with a $5 \% \mathrm{H}_{2} /$ Ar prior to reaction. At the lowest copper loading (i.e., 4 wt.\%), the conversion of Cyhol is relatively low (16\%), while the complete Cyhon selectivity was achieved. Further, with copper loadings from 4 wt.\% to $12 \mathrm{wt} . \%$, the conversion of Cyhol is gradually increased to $42 \%$ and maintained $100 \%$ Cyhon selectivity. Thereafter, above $12 \mathrm{wt}$ \% Cu loadings, the conversion slightly decreased, but selectivity remained $100 \%$. The decline in conversion is due to the physical changes of the Cu particles at higher loadings. Nevertheless, all the catalysts exhibited close $100 \%$ selectivity to Cyhon irrespective of the copper loadings understudied reaction conditions. The $12 \mathrm{Cu} / \mathrm{HSA}-\mathrm{ZnO}$ catalyst showed highest activity in terms of Cyhol conversion of $42 \%$ and $100 \%$ selectivity to Cyhon. The activities of the four catalysts were follow in the ascending order: $4 \mathrm{Cu} / \mathrm{HSA}-\mathrm{ZnO}<8 \mathrm{Cu} / \mathrm{HSA}-\mathrm{ZnO}<16 \mathrm{Cu} / \mathrm{HSA}-\mathrm{ZnO}<12 \mathrm{Cu} / \mathrm{HSA}-\mathrm{ZnO}$. From the activity results, it can be concluded that the 12Cu/HSA-ZnO catalyst presented slightly better performance due to the optimal catalytic properties. 12Cu/HSA-ZnO catalyst was used to further studies on temperature effect and catalyst stability. To determine the relationship between the dehydrogenation of Cyhol and copper content, the turnover frequency (TOF) values were calculated. In Fig.7 presented a plot of TOF against copper loadings. The TOF values gradually increase with copper loadings from 4 to $12 \mathrm{wt}$ \% and then slightly decreased thereafter.

\section{Effect of temperature}


To gain the highest activity and best performance, an optimal reaction temperature was determined was studied over the most active catalyst, i.e., $12 \mathrm{Cu} / \mathrm{HSA}-\mathrm{ZnO}$ in the temperature range of $453-533 \mathrm{~K}$ (Fig. 8). All the main reaction products and possible by-products were shown in Scheme. 2. The conversion of Cyhol increased with reaction temperature and reached to a maximum of around $81 \%$ at $533 \mathrm{~K}$. At the same time, the selectivity of Cyhon is constant up to $473 \mathrm{~K}$ and then decreases with temperature due to the formation of by-products formation and more pronounced side reactions such as Cyhene, Bn, Phol, and Cyhenon formation. For example, the formation of Cyhene is noticed at $493 \mathrm{~K}$ due to the dehydration of Cyhol. From this temperature onward, the Cyhon selectivity gradually decreases and simultaneously, the selectivity to by-products such Cyhon, Phol, $\mathrm{Bn}$ and Cyhenon is increasing. Moreover, the formation of Phol via aromatization of Cyhol reaction pathway occurs at high temperatures. Based on the results, we can conclude that, $513 \mathrm{~K}$ is the most optimal reaction temperature for the vapor phase dehydrogenation Cyhol to Cyhon to gain the best reaction performance with high activity.

\section{Time-on-stream study}

The stability of the $12 \mathrm{Cu} / \mathrm{HSA}-\mathrm{ZnO}$ catalyst was investigated at optimized reaction conditions and the results are depicted in Fig. 9. From the activity results, it can be seen that constant activity was maintained throughout the $12 \mathrm{~h}$ of time on stream. The high activity and stability may be due to optimal metal-support interactions and Cu dispersion with smaller particle size were the salient features of the studied catalyst. For the comparison, the dehydrogenation of Cyhol was studied over low (LSA) and high surface area(HAS)-ZnO based 12Cu/ZnO catalysts at optimal reaction conditions was investigated. Interestingly, over LSA catalysts, $28 \%$ of Cyhol conversion and the $91 \%$ of Cyhon selectivity was achieved, which significantly low conversion compared to HAS-based catalyst (Fig. 10). Over the time on stream for $12 \mathrm{~h}$, the conversion drops to $4 \%$ but the selectivity is intact in case of LSA-based catalyst. The low activity and low stability of the 12Cu/LSA- ZnO catalyst are due to the low dispersion of copper particles over the low surface area $\mathrm{ZnO}$ support.

The possible reaction mechanism for the dehydrogenation of Cyhol to Cyhon over Cu/HSA-ZnO catalysts was shown in Scheme. 3, and the previous reports reveal that the basic properties and copper dispersion play a vital role in the dehydrogenation of alcohols. Moreover, the surface basicity sites of the catalysts are nucleophilic, and thus, the abstract the proton $[\mathrm{H}]$ from the hydroxyl group of Cyhol to form negatively charged alkoxide intermediates. In the next step, the elimination of hydrogen atoms from negatively charged alkoxide intermediates to the formation of Cyhon takes place[32][33][35]. The reported studies in Table 3. were mostly active and selective catalysts with different catalyst compositions and conditions. We reached similar and somewhat better activity results in this work with a novel and simple approach in preparing inexpensive $\mathrm{Cu} / \mathrm{HSA}-\mathrm{ZnO}$ catalyst.

Table 3. Comparison of different Cu-based catalysts reported in the literature on dehydrogenation of cyclohexanol to cyclohexanone. 


\begin{tabular}{|llllll|}
\hline S.NO & Catalyst & Temperature & Conversion & Selectivity & References \\
\hline 1 & $\mathrm{Cu}-\mathrm{MgO}$ & $523 \mathrm{~K}$ & $64.3 \%$ & $100 \%$ & {$[9]$} \\
\hline 2 & $\mathrm{Cu}-\mathrm{MgO}-\mathrm{Cr}_{2} \mathrm{O}_{3}$ & $493 \mathrm{~K}$ & $40 \%$ & $100 \%$ & {$[39]$} \\
\hline 3 & $\mathrm{Cu}-\mathrm{ZnO}-\mathrm{Cr}_{2} \mathrm{O}_{3}$ & $513 \mathrm{~K}$ & $80 \%$ & $60 \%$ & {$[26]$} \\
\hline 4 & $\mathrm{Cu}-\mathrm{ZnO}-\mathrm{Cr}_{2} \mathrm{O}_{3}-\mathrm{La}_{2} \mathrm{O}_{3}$ & $513 \mathrm{~K}$ & $90 \%$ & $67 \%$ & {$[26]$} \\
\hline 5 & $\mathrm{Cu}-\mathrm{SiO}_{2}$ & $523 \mathrm{~K}$ & $60 \%$ & $90 \%$ & {$[40]$} \\
\hline 6 & $\mathrm{Commercial} \mathrm{CuCr}_{2} \mathrm{O}_{4}$ & $523 \mathrm{~K}$ & $30-40 \%$ & $>97 \%$ & {$[10]$} \\
\hline 7 & $\mathrm{Cu}-\mathrm{ZnO}-\mathrm{Graphite}$ & $523 \mathrm{~K}$ & $30-40 \%$ & $>97 \%$ & {$[10]$} \\
\hline 8 & $\mathrm{Cu}-\mathrm{ZnO}-\mathrm{MgO}_{9}$ & $533 \mathrm{~K}$ & $55 \%$ & $99 \%$ & {$[31]$} \\
\hline 9 & $\mathrm{Cu} / \mathrm{carbon}-$ alumina & $553 \mathrm{~K}$ & $41 \%$ & $88 \%$ & {$[41]$} \\
\hline 10 & $\mathrm{Cu}-\mathrm{Ni} / \mathrm{CeO}{ }_{2}$ & $573 \mathrm{~K}$ & $36 \%$ & $89 \%$ & {$[22]$} \\
\hline 11 & $\mathrm{Cu} / \mathrm{HSA}-\mathrm{ZnO}$ & $513 \mathrm{~K}$ & $75 \%$ & $89 \%$ & Present Study \\
\hline
\end{tabular}

The apparent activation energies $\left(E_{a}\right)$ for Cyhol dehydrogenation were calculated from the Arrhenius plot was presented in Fig. 11. The activation energy for Cyhol to dehydrogenation to Cyhon is $4.528 \mathrm{kcal}^{-\mathrm{mol}^{-}}$ ${ }^{1}$, which is relatively low compare to the reported studies for example on $\mathrm{Cu} / \mathrm{ZnO}-\mathrm{MgO}$ catalyst [31].

\subsection{Conclusion}

In summary, we successfully prepared and designed a high surface area ZnO support from a sacrificial template of rice grains. Most importantly, we modified a highly active and selective Cu-based HAS-ZnO based catalysts by a novel facile in-situ thermal decomposition method by using rice grains and zinc acetate. The prepared $\mathrm{Cu} / \mathrm{HAS}-\mathrm{ZnO}$ catalysts presented a better performance than the low surface area commercial ZnO based catalysts in vapor phase dehydrogenation Cyhol to Cyhon. The effect of $\mathrm{Cu}$ loadings on final catalytic properties is more pronounced and significant in terms of activity and selectivity. Over $12 \mathrm{wt}$ \% $\mathrm{Cu} / \mathrm{HSA}-\mathrm{ZnO}$ catalysts exhibited superior performance and long-term stability compared to all other catalysts due to the optimal dispersion of copper particles over rice-derived high surface area $\mathrm{ZnO}$ and basicity character. Among all the synthesized catalysts, $12 \mathrm{Cu} / \mathrm{HSA}-\mathrm{ZnO}$ catalyst showed high activity in conversion of Cyhol is $75 \%$ and selectivity to Cyhon is $89 \%$ at $513 \mathrm{~K}$ reaction temperature under atmospheric pressure.

\section{Declarations}

Acknowledgments: The author thanks the Council of Scientific \& Industrial Research (CSIR), New Delhi, for the award of Senior Research Fellowship. 
Conflicts of Interest: The authors declare no conflict of interest

Author Contributions: K.S.K (conceptualization) (writing-original draft) (software), N.N (writing introduction, data analysis, results interpretation and curation) (methodology), B.P (software), H.S (validation), P.K.S (interpretation and curation), V.P (supervision). B.P.K (conceptualization,writing-review and editing), All authors have read and agreed to the published version of the manuscript

\section{References}

1. N. Baig, I. Kammakakam, W. Falath, I. Kammakakam, Mater. Adv. 2, 1821 (2021)

2. Y. Xie, D. Kocaefe, C. Chen, Y. Kocaefe, Rev. Res. Template Methods Nanomater. 2016, (2016)

3. W. Li, D. Zhao, Chem. Commun. 49, 943 (2013)

4. J. Gao, K.J. Sawant, J.T. Miller, Z. Zeng, D. Zemlyanov, J.P. Greeley, ACS Appl. Mater. Interfaces 13, 35113 (2021)

5. P. Chhattise, S. Saleh, V. Pandit, S. Arbuj, V. Chabukswar, Mater. Adv. 1, 2339 (2020)

6. A. Moumen, N. Kaur, N. Poli, D. Zappa, E. Comini, Nanomaterials 10, 1 (2020)

7. V.Z. Fridman, A.A. Davydov, A.A. Davydov, J. Catal. 195, 20 (2000)

8. F.M.T. Mendes, M. Schmal, Appl. Catal. A Gen. 151, 393 (1997)

9. B.M. Nagaraja, V. Siva Kumar, V. Shashikala, A.H. Padmasri, S. Sreevardhan Reddy, B. David Raju, K.S. Rama Rao, J. Mol. Catal. A Chem. 223, 339 (2004)

10. A. Romero, A. Santos, D. Escrig, E. Simón, Appl. Catal. A Gen. 392, 19 (2011)

11. N.P. Tangale, P.S. Niphadkar, S.S. Deshpande, P.N. Joshi, Appl. Catal. A Gen. 467, 421 (2013)

12. E. Simón, J.M. Rosas, A. Santos, A. Romero, Catal. Today 187, 150 (2012)

13. D. Ji, W. Zhu, Z. Wang, G. Wang, Catal. Commun. 8, 1891 (2007)

14. E. Simón, J.M. Rosas, A. Santos, A. Romero, Chem. Eng. J. 214, 119 (2013)

15. C. Soumini, S. Sugunan, S. Haridas, J. Porous Mater. 26, 631 (2019)

16. B. Sridevi, P. Nagaiah, A.H. Padmasri, B.David Raju, K.S. Rama Rao, J. Chem. Sci. 129, 601 (2017)

17. M. Popova, M. Dimitrov, V.D. Santo, N. Ravasio, N. Scotti, Catal. Commun. 17, 150 (2012)

18. D.V. Cesar, C.A. Peréz, V.M.M. Salim, M. Schmal, Appl. Catal. A Gen. 176, 205 (1999)

19. X. Li, B. Liang, J. Taiwan. Inst. Chem. Eng. 43, 339 (2012)

20. M. Popova, Á Szegedi, K. Lázár, A. Dimitrova, Catal Lett. 141, 1288 (2011)

21. F.M. Bautista, J.M. Campelo, A. García, D. Luna, J.M. Marinas, R.A. Quirós, A.A. Romero, Appl. Catal. A Gen. 243, 93 (2003)

22. G. Ranga Rao, S.K. Meher, B.G. Mishra, P.H.K. Charan, Catal. Today 198, 140 (2012)

23. Y. Gao, E.J.M. Hensen, J. Catal. 384, 218 (2020)

24. P. Nagaiah, C.V. Pramod, M. Venkata Rao, B. David, Raju, and K. S. Rama Rao, Catal. Letters 148, $3042(2018)$ 
25. Y. Gao, E.J.M. Hensen, Catal. Commun. 117, 53 (2018)

26. V. Siva Kumar, S. Sreevardhan Reddy, A.H. Padmasri, B.David Raju, I. Ajitkumar Reddy, K.S. Rama Rao, Catal. Commun. 8, 899 (2007)

27. L. Ma, X. Zhang, D. Lin, Y. Chun, Q. Xu, Appl. Catal. A Gen. 460-461, 26 (2013)

28. L. Wang, C. Di, T. Li, Y. Chun, Q. Xu, Catal. Sci. Technol. 5, 5185 (2015)

29. K.S. Koppadi, R.R. Chada, S.S. Enumula, R.K. Marella, S.R.R. Kamaraju, D.R. Burri, Catal Lett. 147, 1278 (2017)

30. K.S. Koppadi, R.R. Chada, V.R.B. Gurram, S.R. Kancharakuntla, S.R.R. Kamaraju, D.R. Burri, ChemistrySelect 3, 3079 (2018)

31. S.V. Sancheti, G.D. Yadav, Mol. Catal. 506, 111534 (2021)

32. R.K. Marella, C.K. Prasad Neeli, S.R. Rao, Kamaraju, D.R. Burri, Catal. Sci. Technol. 2, 1833 (2012)

33. R. Shi, F. Wang, Y. Tana, X. Li, Huang, W. Shen, Green. Chem. 12, 108 (2010)

34. M. Zhang, Y. Zhao, Q. Liu, L. Yang, G. Fan, F. Li, Dalt Trans. 45, 1093 (2016)

35. B.M. Nagaraja, A.H. Padmasri, P. Seetharamulu, K. Hari Prasad Reddy, B.David Raju, K.S. Rama Rao, J. Mol. Catal. A Chem. 278, 29 (2007)

36. M. Gliński, U. Ulkowska, E. Iwanek, J. Chem. Educ. 93, 1623 (2016)

37. G. Krishna Reddy, K.S. Rama Rao, P. Kanta Rao, Catal Lett. 59, 157 (1999)

\section{Scheme}

Scheme 1,2 and 3 is available in supplementary section.

\section{Figures}




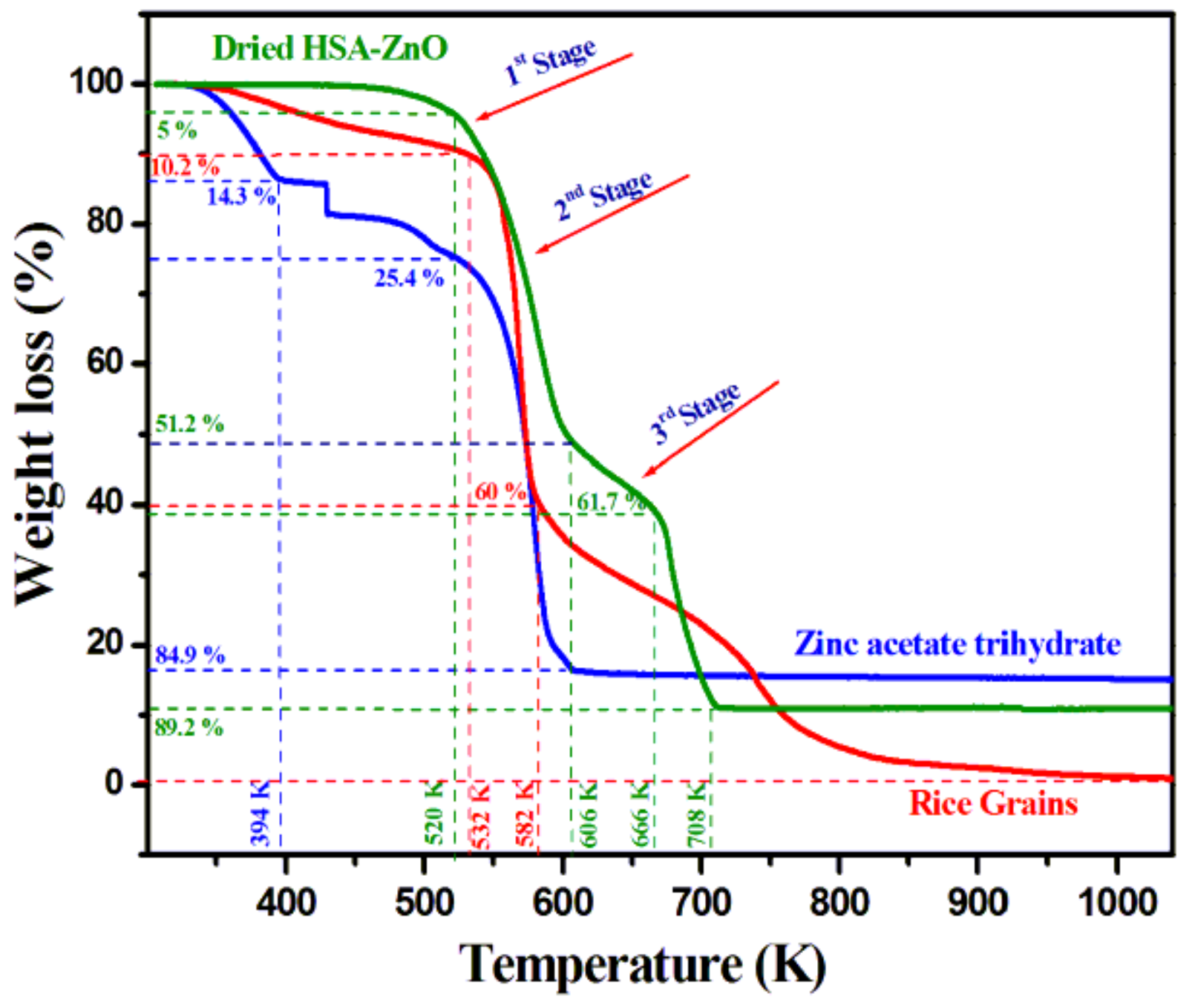

Figure 1

TGA analysis of dried HSA-ZnO support, zinc acetate precursor and the rice grains. 


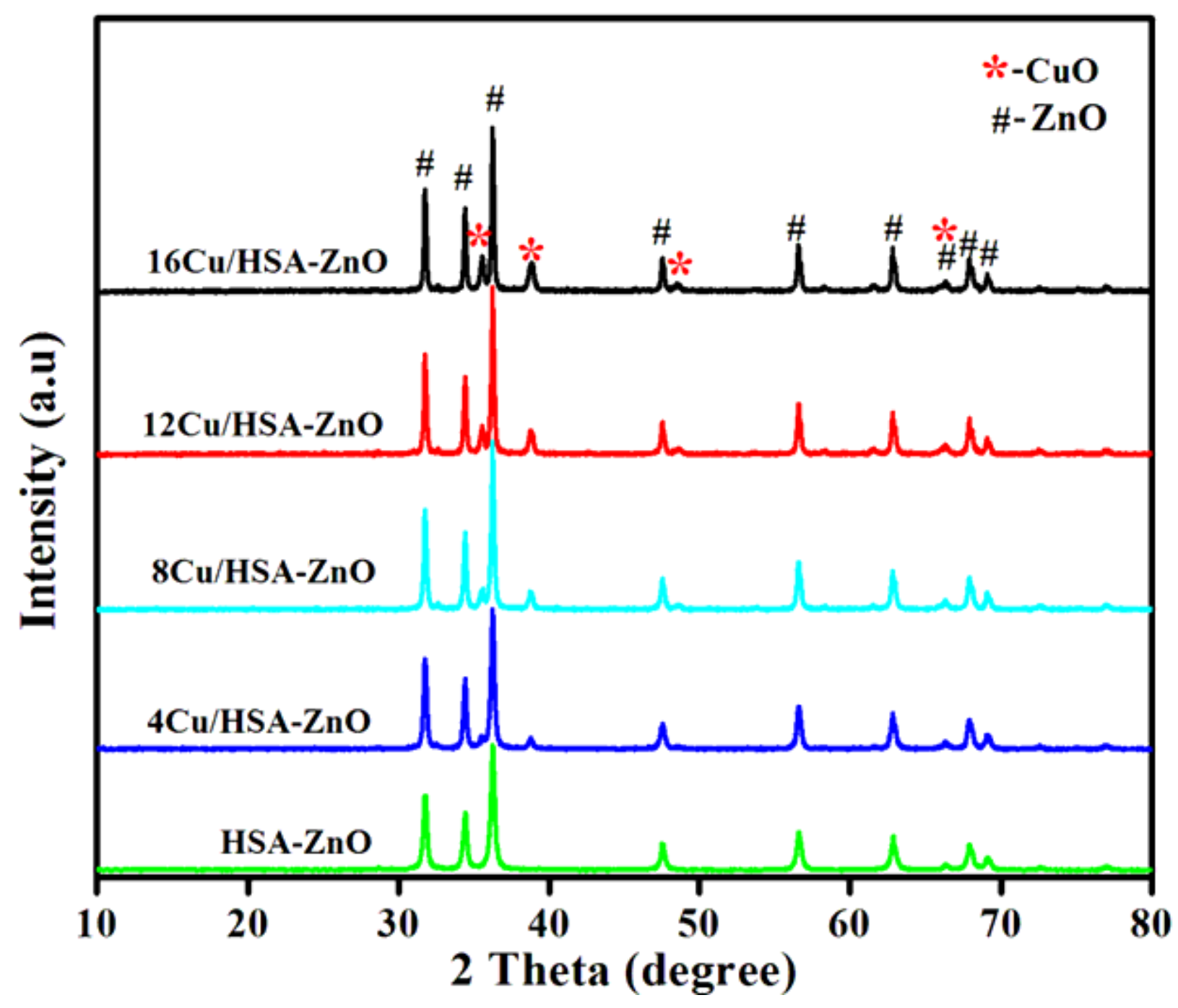

Figure 2

XRD patterns of $\mathrm{HSA}-\mathrm{ZnO}$ and calcined $\mathrm{Cu} / \mathrm{HSA}-\mathrm{ZnO}$ catalysts. 


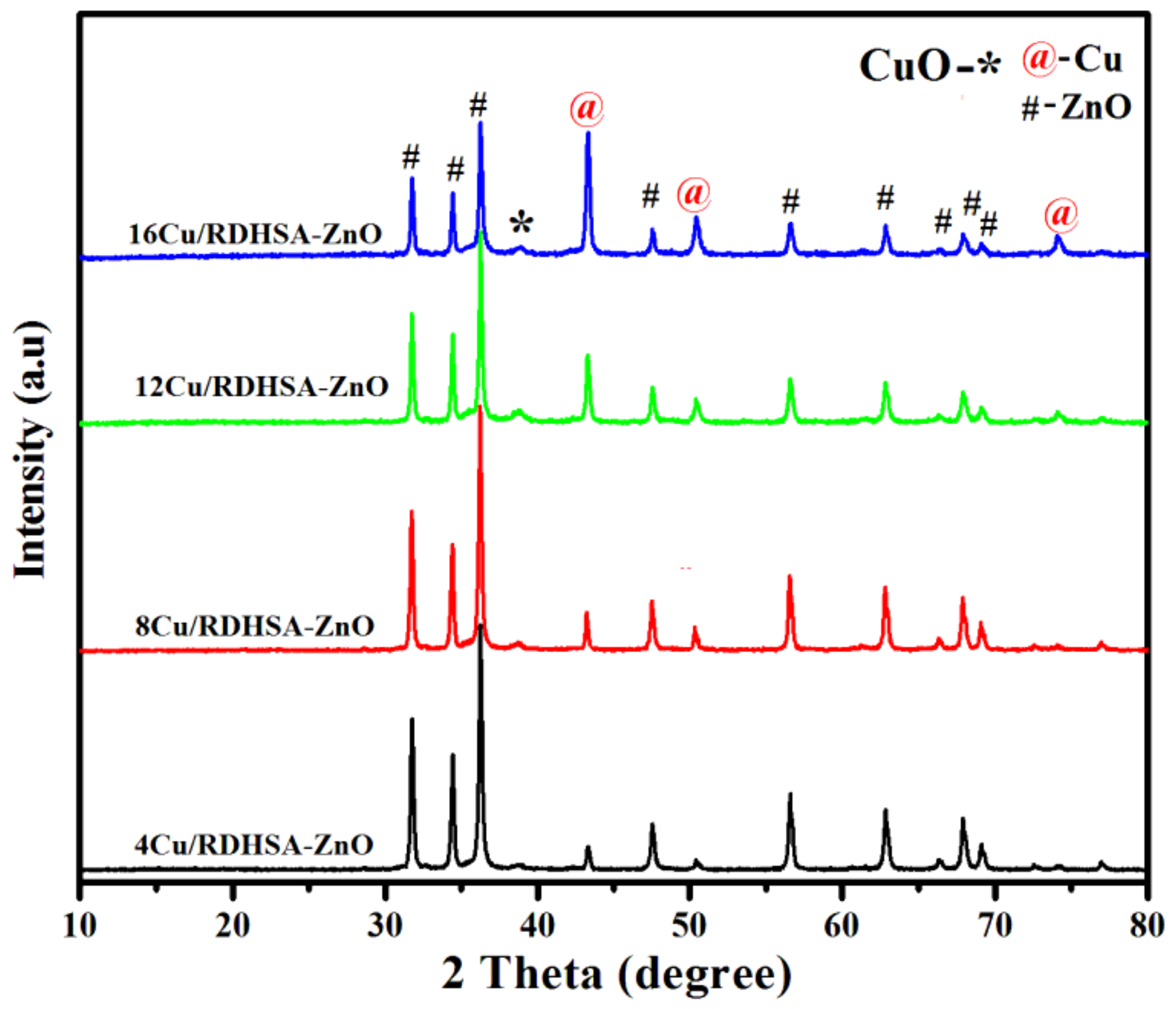

Figure 3

XRD patterns of reduced $\mathrm{Cu} / \mathrm{HSA}-\mathrm{ZnO}$ catalysts. 


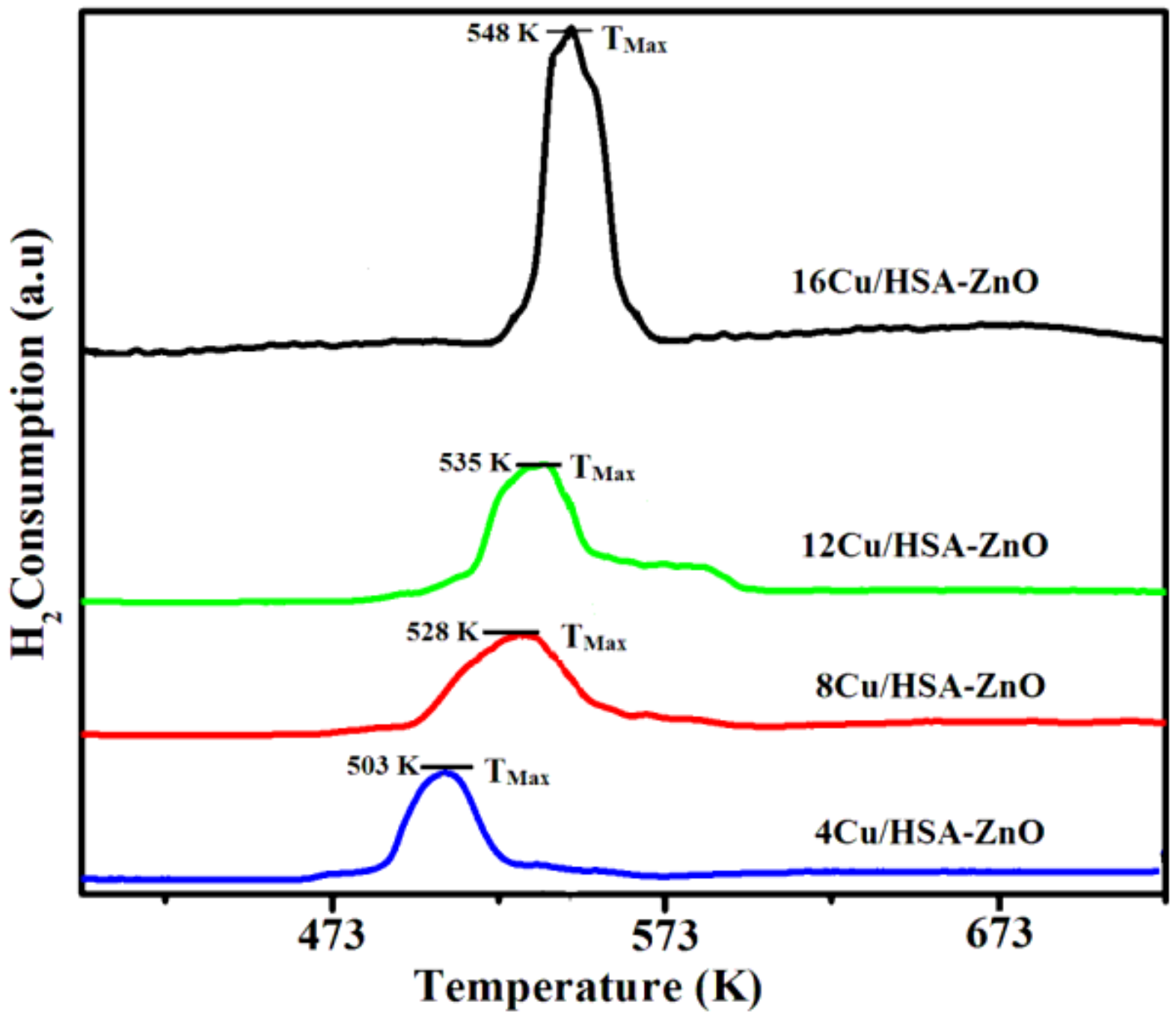

Figure 4

$\mathrm{H}_{2}$-TPR profile of calcined $\mathrm{Cu} / \mathrm{HSA}-\mathrm{ZnO}$ catalysts. 


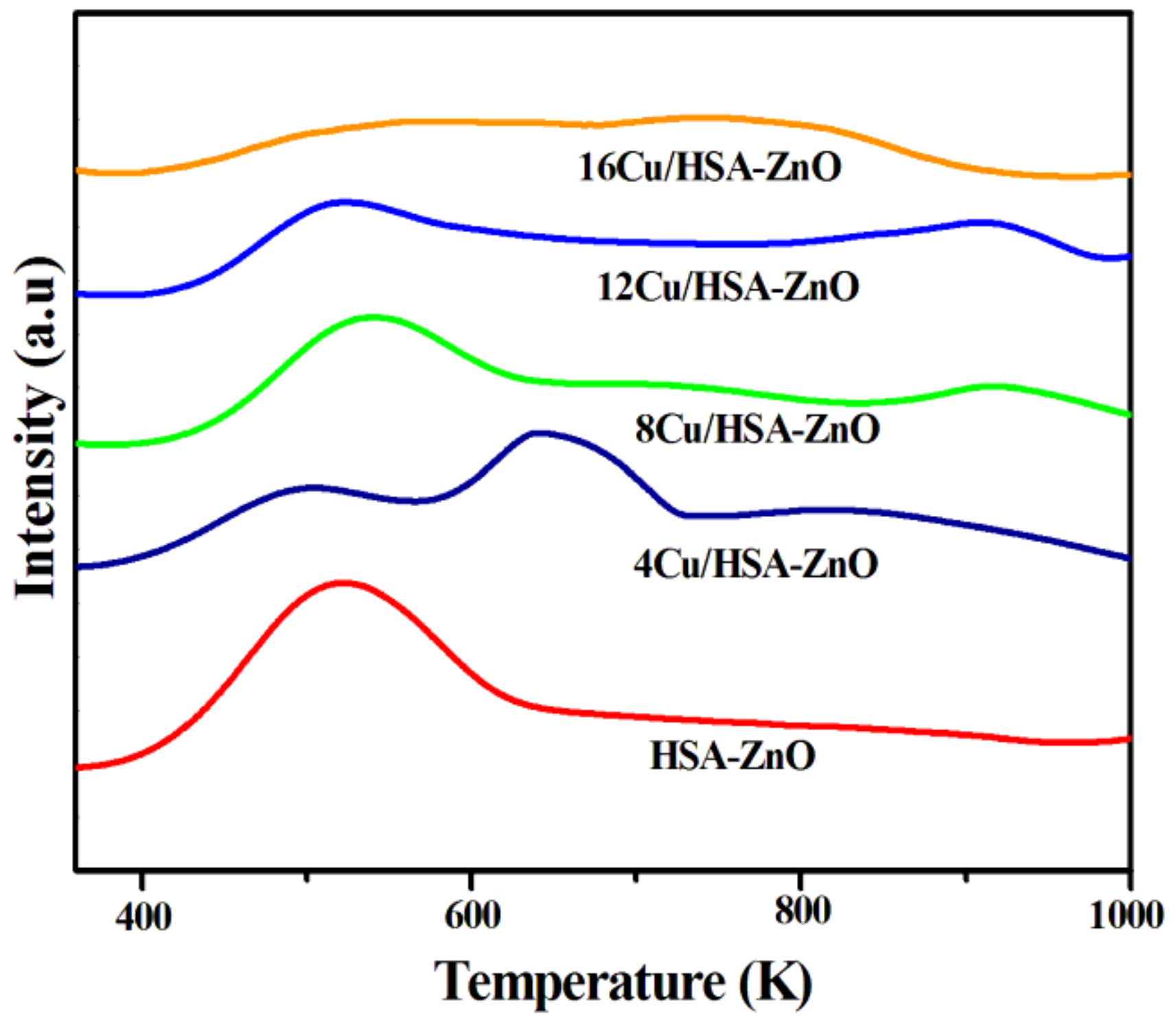

Figure 5

The $\mathrm{CO}_{2}$-TPD profile of $\mathrm{HSA}-\mathrm{ZnO}$ and $\mathrm{Cu} / \mathrm{HSA}-\mathrm{ZnO}$ catalysts 


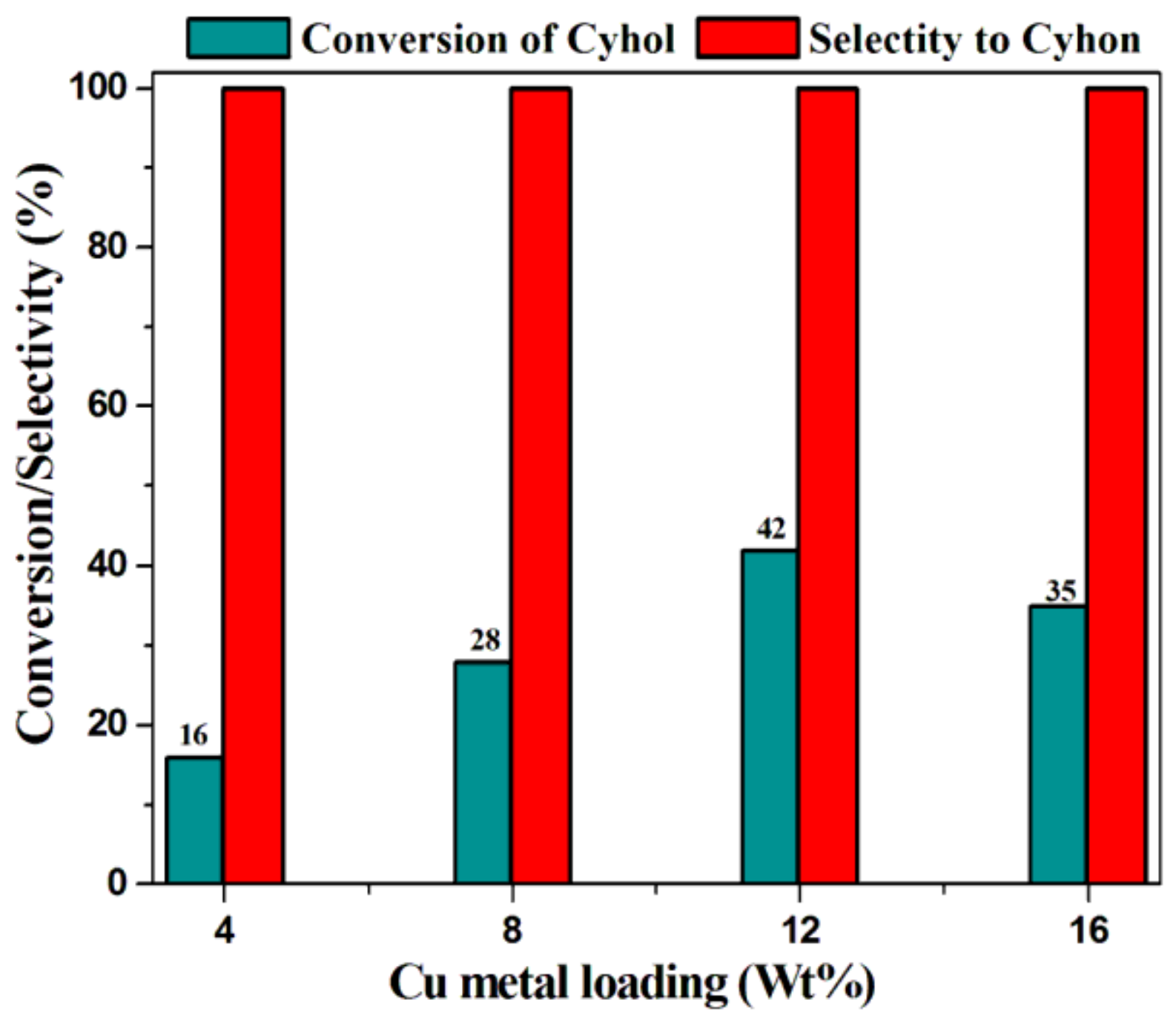

Figure 6

Effect of copper loading for the dehydrogenation of Cyhol to Cyhon. Reaction conditions: catalyst weight $0.5 \mathrm{~g}$, Reaction temperature $453 \mathrm{~K}, \mathrm{~N}_{2}$ flow: $25 \mathrm{~mL} \mathrm{~min}^{-1}$, Liquid feed flow: $1 \mathrm{~mL} \mathrm{~h}^{-1}$ 


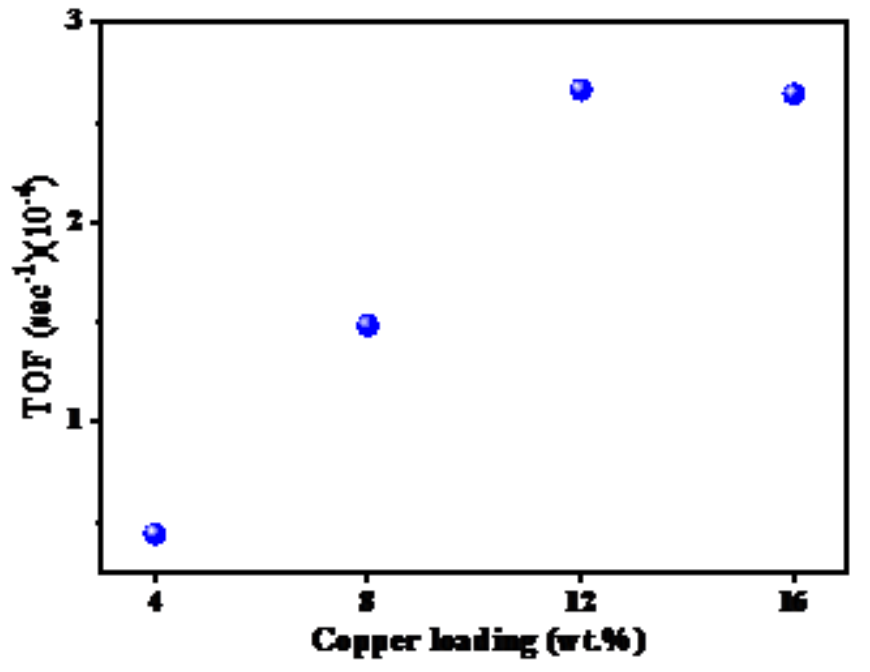

Figure 7

TOF values over $\mathrm{Cu} / \mathrm{HSA}-\mathrm{ZnO}$ catalysts with various copper loadings.

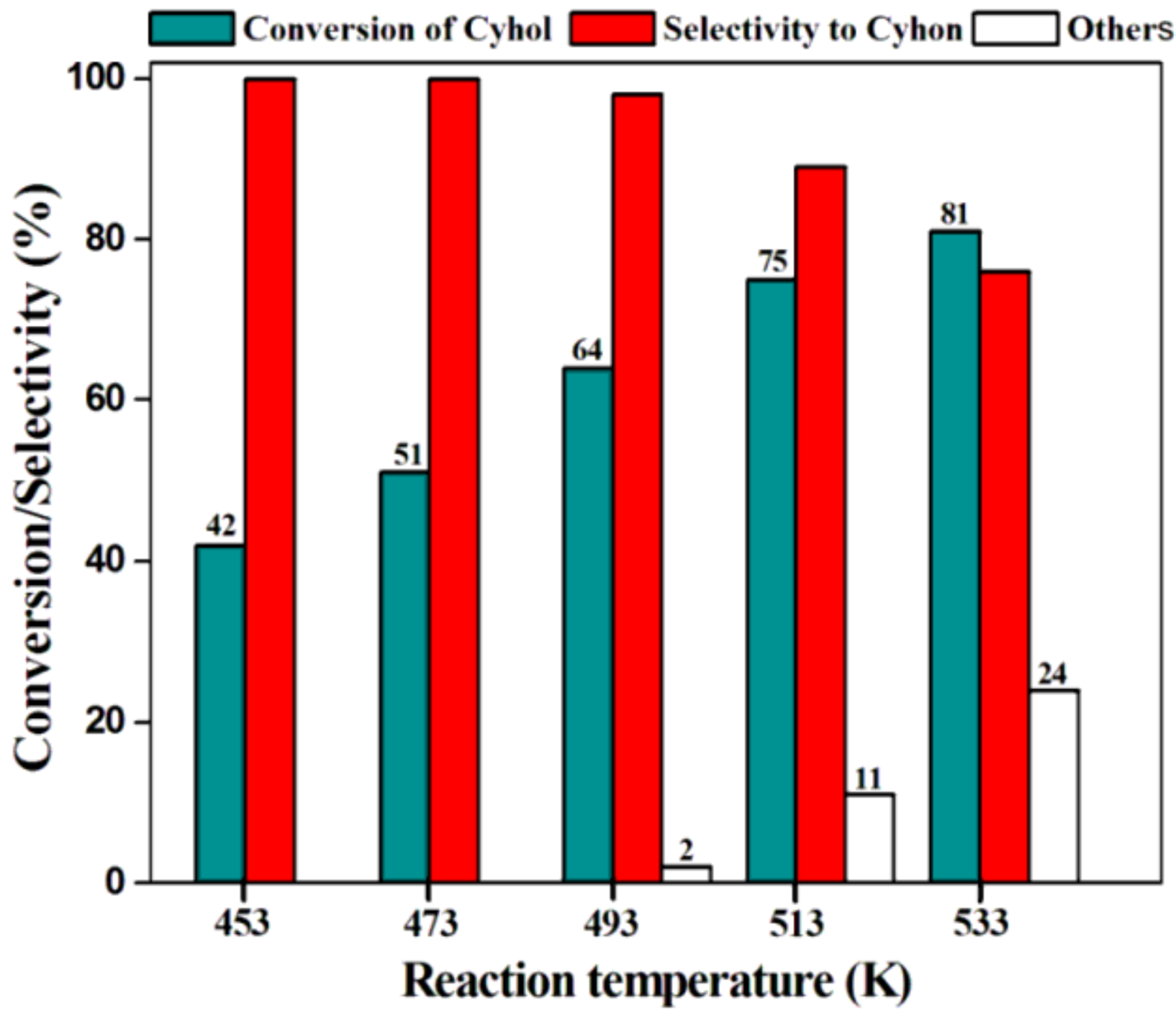


Figure 8

Influence of temperature on dehydrogenation of Cyhol to Cyhon over 12Cu/HSA-ZnO catalyst. Reaction conditions: catalyst weight: $0.5 \mathrm{~g}, \mathrm{~N}_{2}$ flow: $25 \mathrm{~mL} \mathrm{~min}^{-1}$, Liquid feed flow: $1 \mathrm{~mL} \cdot \mathrm{h}^{-1}$

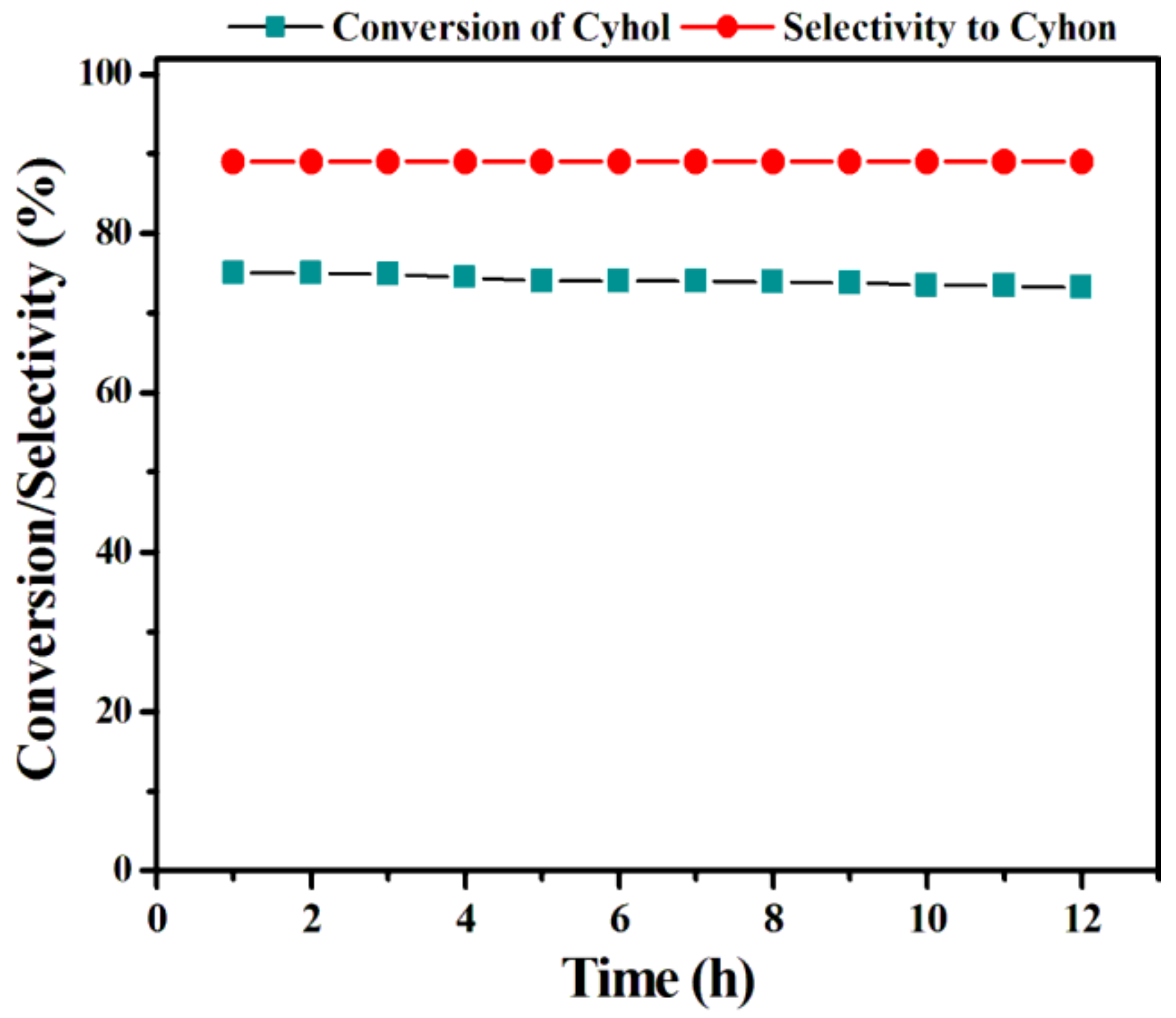

Figure 9

Time-on-stream study of dehydrogenation Cyhol to Cyhon over Cu/HSA-ZnO catalyst; Reaction conditions: catalyst weight $0.5 \mathrm{~g}$, Reaction temperature: $513 \mathrm{~K}, \mathrm{~N}_{2}$ flow: $25 \mathrm{~mL} \mathrm{~min}^{-1}$, Liquid feed flow: 1 $\mathrm{mL} \mathrm{h} \mathrm{h}^{-1}$ 


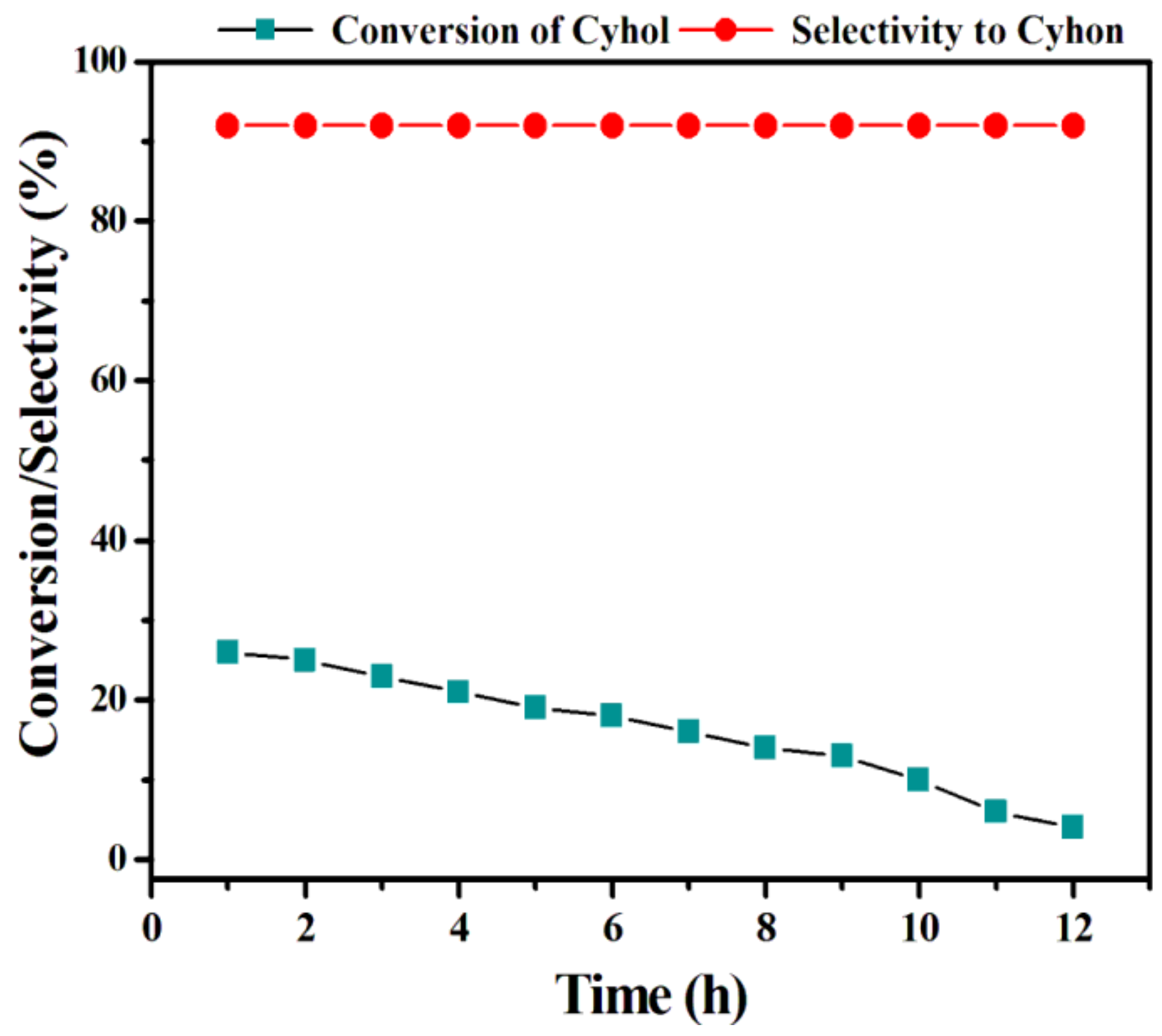

Figure 10

Time-on-stream study of dehydrogenation Cyhol to Cyhon over Cu/LSA-ZnO catalyst; Reaction conditions: catalyst weight $0.5 \mathrm{~g}$, Reaction temperature: $513 \mathrm{~K}, \mathrm{~N}_{2}$ flow: $25 \mathrm{~mL} \mathrm{~min}^{-1}$, Liquid feed flow: 1 $\mathrm{mL} \mathrm{h} \mathrm{h}^{-1}$ 


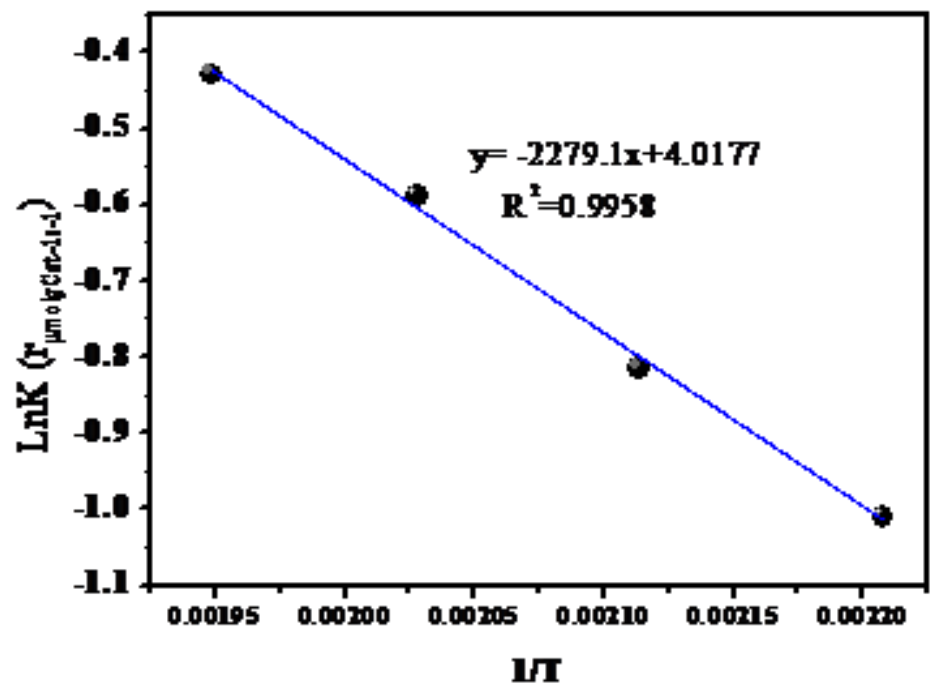

Figure 11

Arrhenius plot for the dehydrogenation of Cyhol to Cyhon over $12 \mathrm{Cu} / \mathrm{HSA}-\mathrm{ZnO}$ catalyst.

\section{Supplementary Files}

This is a list of supplementary files associated with this preprint. Click to download.

- SupplymentaryInformation1.docx

- Onlinefloatimage6.png

- Onlinefloatimage9.png

- Onlinefloatimage13.png 